\title{
'MONUMEN KREWENG' 3D ANIMATION VIDEO AS A VISUAL BRANDING STRATEGY FOR JURON TOURIST VILLAGE
}

\author{
Aries Budi Marwanto ${ }^{1}$, Damar Tri Afrianto ${ }^{2}$ and NRA. Chandra Dwi Atmaja ${ }^{3}$ \\ ${ }^{1}$ Institut Seni Indonesia (ISI) Surakarta, Indonesia \\ 2 Institut Teknologi Telkom (ITT) Purwokerto, Indonesia \\ ${ }^{3}$ Institut Seni Indonesia (ISI) Surakarta, Indonesia \\ E-mail: aries.be.em@gmail.com
}

\begin{abstract}
The development of tourist destinations in this digital era focuses on using technology to develop successful tourism recovery during the pandemic era. We use this principle to develop a tourism strategy using 3D animated videos to introduce Juron Village as a tourist village. Specifically, this study analyzes the visual strategy of a 3D animation video entitled "Monumen Kreweng" using Marty Neumeier's visual branding analysis. The findings provide insight into the animated video's visual branding strategies, including differentiation, collaboration, innovation, validation, and cultivation. The differentiation is found in the work of the Kreweng monument as the focal point of attention and local wisdom, followed by validation through the use of social media platforms to solicit consumer feedback on visual branding. Finally, the cultivation concept encourages various stakeholders to participate in realizing Juron Village's tourism branding.
\end{abstract}

Keywords: $3 D$ animation, video, visual branding, and tourism

\begin{abstract}
ABSTRAK
Pengembangan destinasi wisata di era digital ini fokus pada pemanfaatan teknologi sebagai strategi untuk keberhasilan pemulihan pariwisata selama pandemi. Prinsip ini yang dipakai untuk mengembangkan strategi pariwisata dengan menggunakan video animasi 3D sebagai upaya mengangkat Desa Juron sebagai desa wisata. Penelitian ini mencoba menganalisis strategi visual video animasi 3D yang berjudul "Monumen Kreweng". Metode yang digunakan yaitu analisis visual branding Marty Neumeier. Penelitian ini menghasilkan sebuah pemahaman bahwa dalam karya ini telah memuat strategi visual branding yaitu diferensiasi, kolaborasi, inovasi, validasi dan cultivate. Diferensiasi terdapat pada karya monumen kreweng sebagai pusat perhatian dan kearifan lokal, kemudian validasi dilakukan dengan memanfaatkan platform media sosial untuk memberikan umpan balik dari konsumen tentang visual branding, dan konsep cultivate mendorong berbagai pihak untuk ikut serta dalam mewujudkan branding Desa Wisata Juron.
\end{abstract}

Kata kunci: Video, animasi 3D, visual branding, dan pariwisata

\section{PENDAHULUAN}

Pemerintah saat ini meyakini

pengembangan industri pariwisata

merupakan salah satu upaya yang

dianggap mampu dengan cepat

meningkatkan dan mewujudkan

kesejahteraan masyarakat. Pada tahun

2016 pemerintah menetapkan sebagai tahun percepatan akselerasi dalam rangka mewujudkan pencapaian target pembangunan di masing-masing sektor dengan menargetkan kunjungan wisatawan macanegara sebanyak 12 juta wisatawan (http://www.kemenpar.go.id, diakses 20 Desember 2018). Kemudian, pada tahun 2018 pemerintah kembali menempatkan 
industri pariwisata pada urutan kedua untuk program rencana kerja pemerintah, artinya kini pemerintah berharap penuh industri pariwisata mampu memberikan sumbangan devisa untuk kelangsungan perekonomian negara. Kini di tahun 2021, akselarasi itu terus dipacu dengan menggandeng perangkat teknologi digital. Peranan digital memiliki peran besar dalam pengembanagan pariwisata di beberapa sektor.

Pengembangan pariwisata di era digital ini difokuskan pada pemanfaatan teknologi sebagai strategi utama kekuatan yang menjadi tonggak keberhasilan pemulihan pariwisata. Pemerintah dalam hal ini penting mendorong industri pariwisata untuk memiliki kesadaran digital literer. Digital literer adalah pemahaman kepada masyarakat melalui perangkat digital audiovisual yang memberi gambaran calon wisatawan tentang sebuah destinasi wisata. Konkretnya, pihak pelaku wisata mengemas destinasi wisata dalam bentuk konten video kreatif, kemudian dipublikasikan melalui jejaring informasi digital. Dalam hal ini, masyarakat diyakinkan dengan konten digital tersebut, sehingga menarik calon wisatawan dan menjadikan pertimbangan yang matang untuk berwisata secara aman. Inilah kerja digital literer untuk industri pariwisata.

Strategi branding menggunakan video menjadi pilihan utuma di era digital. Video merupakan keseluruhan unsur visual yang mendominasi terhadap persepsi dari sebuah pesan yang diiklankan. Oleh karena itu, para pembuat iklan menggunakannya sebagai konsep utama. Unsur-unsur dari video mencakup semua hal yang terlihat pada layar. Para pembuat iklan menggunakan unsur visual untuk menyampaikan pesan sebanyak mungkin kepada penontonnya. Emosi akan lebih meyakinkan apabila diekspresikan baik melalui raut wajah, gerak badan, ataupun bahasa tubuh lainnya. Para pembuat iklan video yang baik seharusnya lebih mengedepankan dampak dari unsur visual daripada kata-kata ataupun dialog yang tidak begitu penting. Iklan video yang sukses adalah iklan yang berhasil mengkoordinasikan dengan baik sejumlah besar unsur-unsur visual yang terdapat di dalamnya (William Wells, John Burnett dan Sandra Moriarty, 1992).

Prinsip inilah yang saat ini dikembangkan oleh masyarakat Desa Juron, Kabupaten Sukoharjo, Jawa Tengah. Desa Juron memiliki potensi wisata sejak lama melalui kebudayaan dimilikinya, namun desa ini menjadi tertinggal, karena hampir sebagai besar masyarakatnya merantau ke kota-kota besar. Dengan keterbatasan itulah, masyarakat Desa Juron mengembangkan strategi pariwisata dengan menggunakan video animasi 3D sebagai upaya mengangkat desa Juron sebagai Desa Wisata. 


\section{CAPTURE}

Video animasi 3D berjudul "Monumen Kreweng". Materi video animasi 3D berisi lanskap pengembangan Desa Wisata Juron dengan mengenalkan "Monumen Kreweng" sebagai ikon wisata. "Kreweng" menurut Kamus Besar Bahasa Indonesia merupakan pecahan benda yang terbuat dari tanah liat atau tembikar. "Kreweng" sebagai judul penelitian artistik ini mewakili penamaan benda seperti anglo, kuali, kendi, cowek, dandang, kendil, genthong, wajan dan lain-lain yang terbuat dari tanah liat yang digunakan sebagai perkakas dapur tradisional. Kreweng merupakan kearifan lokal di Desa Juron yang memiliki nilai-nilai tradisi yang masih dipegang secara turun-temurun.

Hal yang menarik dari video animasi $3 \mathrm{D}$ tersebut yaitu bagaimana video tersebut mampu memberi kepercayaan baik internal maupun eksternal. Internal dalam hal ini membangkitkan rasa optimisme warga Desa Juron dalam menuju desa wisata, sedangkan aspek eksternalnya, video mampu mengenalkan Desa Juron tentang potensi wisata dan kekayaan tradisi yang dimiliki yaitu kreweng itu sendiri. Oleh karenanya, dalam penelitian ini mencoba menganalisis strategi visual pada video animasi 3D yang berjudul "Monumen Kreweng" dalam upaya pengembangan desa wisata. Diharapkan dengan adanya penelitian video animasi 3D "Monumen Kreweng" dapat menemukan strategi dalam pemanfaatan konten digital sebagai pengembangan pariwisata, sebagaimana pernyataan Koko Is Prayogo dan Ranang Agung Sugihartono (2016), pada akhirnya banyak hal yang dapat disampaikan pada masyarakat dengan karya audio visual yang bernuansa lokal.

\section{TINJAUAN PUSTAKA}

Strategi visual merupakan usaha atau aktivitas menerapkan elemen visual untuk kepentingan dan keperluan tertentu. Elemen visual dalam hal ini sebagai perangkat komunikasi yang berfungsi menyampaikan gagasan atau sebuah pesan. Pada titik ini, strategi visual adalah rangkaian proses penyampaian informasi atau pesan kepada pihak lain dengan menggunakan media penggambaran yang terbaca oleh indera penglihatan. Strategi visual layaknya sebuah siasat bahasa visual yang dapat digunakan untuk menerjemahkan pikiran dalam bentuk visual. Perannya bukan hanya memberi seni dan rupa pada benda, tetapi juga menerjemahkan jiwa yang relevan dengan perkembangan zaman dan teknologi.

Strategi visual erat kaitannya dengan identitas atau branding, karena elemen visual memungkinkan menciptakan suatu identitas dalam sebuah objek. Brand dapat dipahami sebagai sebuah citra yang terbentuk ketika sebuah 'produk' berinteraksi dengan pelanggannya. Brand bersifat abstrak, karena memuat beberapa strategi komersialiasi 'produk' baik yang 
bersifat filosofis, politis maupun ekonomis (Noorwata dan Wirawan, 2020). Upaya mem-branding sebuah objek penting untuk mempertimbangkan visual branding sebagai strateginya, Visual branding adalah berbagai elemen visual yang digunakan oleh sebuah brand untuk membangun karakter dan identitas 'bisnis', seperti bentuk logo, warna logo, typeface, tagline, warna tema brand, komposisi desain, dan berbagai elemen visual lainnya (Julizar dalam Noorwatha dan Wirawan, 2020).

Strategi visual branding sangat penting untuk ditentukan arah brand untuk dikomunikasikan. Strategi harus merinci area seperti memahami audiens brand, pasarnya (termasuk pesaing) dan juga harus berintegrasi dengan visi objek yang ingin dikomunikasikan. Visual branding dapat dibentuk melalui kemampuan dalam mengolah informasi melalui visual, sehingga dapat menarik perhatian meskipun berkaitan dengan isu politik yang cenderung formal dan kaku. Visual branding merupakan pengaruh yang diakibatkan oleh suatu bentuk visual untuk mendiferensiasikan brand (Budiman, 1998).

Dalam dunia modern ini, strategi visual menjadi medium dan gagasan utama komunikasi dan sekaligus akses yang diandalkan untuk memahami kekayaan realitas. Strategi budaya visual berkonsentrasi pada penglihatan atau tatapan terhadap informasi yang memiliki sebuah nilai atau hanya sekedar sebuah hiburan yang ditentukan oleh konsumen melalui teknologi visual (Santo, 2019).

Melalui beberapa tinjauan terkait strategi visual branding yang telah dipaparkan, strategi visual mampu memiliki kekuatan dalam mem-branding sebuah objek untuk mengkonstruksi sebuah identitas. Strategi tersebut sering digunakan salah satunya untuk pengembangan wisata. Strategi kreatif yang digunakan dalam perancangan komunikasi visual branding Desa Juron adalah dengan mengangkat unsur-unsur kebudayaan yang memiliki kekhasan, yaitu tradisi kreweng yang berkembang di desa

Visual branding tentu melalui sebuah tahapan dan proses. Tahapan itu dalam mendukung sebuah objek untuk mampu memiliki kekhasan dan identitas, dalam bahasa komunikasi dikenal istilah dengan Top of Main, suatu luaran dari sebuah branding. Top of Main memainkan peran komunikasi terpusat, dalam arti persepsi masyarakat atau publik akan digiring pada makna yang telah dibuat melalui branding terutama visual. Analisis strategi branding yang mendalam akan memberikan sebuah gambaran seberapa kuat dan intensitas praktik visual branding bekerja dalam membentuk Top of Main. Marty Neumeier dalam bukunya The Brand Gap merumuskan visual branding menjadi 5 tahap disiplin: differentiate atau 
differensiasi, collaboration atau kolaborasi, innovate atau inovasi, validate atau validasi, cultivate atau mengolah. Berikut penjelasan tahap-tahapnya:

a) Differentiate: Sudut pandang desain tradisional memiliki tujuan yang paling memungkinkan yaitu: to identify, to inform, to entertain dan to persuade, akan tetapi dengan branding ada satu tujuan yang harus dimiliki yaitu to differentiate (Neumier, 2006). Sebuah produk harus memiliki pembeda yang unik dengan produk lain. Pembeda tersebut bisa berasal dari kategori produknya, segmentasi, dan kualitas.

b) Collaboration: Brand building tidak bisa dikerjakan semuanya oleh produsen. Produsen design harus berkolaborasi dan saling berinteraksi dengan konsumen untuk menentukan desain yang baik dan tepat sasaran, sehingga brand mereka bisa menjadi Top of Mind.

c) Innovate: Setiap brand yang ingin terus berada dalam benak konsumen serta mampu bersaing secara kompetitif dengan konsumen tidak dapat menghindari hal yang disebut dengan inovasi. Dengan adanya inovasi, brand akan menjadi tetap segar atau tidak kehilangan kharismanya (Neumier, 2006). Dengan adanya inovasi, setiap brand akan menjadikan brand mampu mengikuti perkembangan zaman dan selera konsumen. d) Validate: Standar model dari sebuah proses komunikasi terdiri atas tiga komponen yaitu: sender atau pengirim informasi, message atau pesan, dan receiver atau penerima. Pengirim informasi (perusahaan) menyusun sebuah pesan (webpage, iklan, brosur, direct mail dII.) dan mengirimkannya kepada receiver (target audience) dan sebuah proses komunikasi pun dapat selesai. Namun, Neumier (2006) berpendapat model komunikasi seperti itu dapat dikatakan kurang sempurna dan bahkan salah, karena dalam model komunikasi seperti itu pengirim pesan (perusahaan) cenderung tidak tahu, bahkan tidak perduli bagaimana yang terjadi sebenarnya dengan apa yang penerima pesan (target audience) rasakan. Model komunikasi seperti ini cenderung terjadi satu arah dan tanpa adanya feed back dari penerima pesan. Sehingga, tingkat penerimaan target audience perlu dilacak dan diketahui, biasanya survey dilakukan untuk melihat tingkat penerimaan khalayak.

e) Cultivate: Sebuah brand yang hidup merupakan kolaborasi dari kinerja dan semua orang di dalamnya (Neumier, 2006). Dalam pernyataan Marty Neumier tersebut memiliki arti bahwa segala sumber daya manusia yang ada dalam perusahaan memiliki peran penting dalam proses membangun brand, setelah melakukan proses 
diferensiasi, kolaborasi, inovasi, dan validasi. Tahap akhir membangun sebuah brand yang kuat ialah manajemen brand tersebut tetap "hidup" atau mampu menghadapi persaingan dengan kompetitor yang setiap saat selalu ada.

\section{METODE}

Metode dalam penelitian ini menggunakan metode kulitatif interpretatif. Metode ini tidak sekedar mendeskripsikan, tetapi lebih penting menemukan makna yang terkandung di baliknya (Ratna, 2010).

Metode ini mensyaratkan analisis mendalam dalam sebuah objek penelitian. Metode interpreatif ini didukung dengan teori visual branding dari Marty Neumeier. Analisis strategi branding yang mendalam akan memberikan sebuah gambaran seberapa kuat dan intensitas praktik visual branding bekerja dalam membentuk Top of Main. Hasil analisis data disajikan sesuai dengan tahapan visual branding.

\section{PEMBAHASAN}

Karya video animasi 3D berjudul "Monumen Kreweng" dalam penelitian ini dianalisis dalam kaitannya dengan teori visual branding. Sehingga, pembacaan terhadap karya ini memungkinkan menjadi sebuah proyeksi terkait brand pariwisata Desa Juron. Video animasi 3D ini berdurasi 7.25 menit memuat master plan desa wisata dengan Monumen Kreweng sebagai center of interest-nya. Analisis visual branding video animasi 3D "Monumen Kreweng" sebagai berikut.

\subsection{Diferensiasi}

Karya ini memuat gambaran yang cukup jelas tentang proyeksi desa wisata di daerah Juron, Sukoharjo. Konsep diferensiasi pada karya ini terlihat pada Monumen Kreweng yang menjadi pusat perhatian. Monumen Kreweng ini menjadi pembeda daerah daerah lain karena mengangkat kearifan lokal yaitu kreweng. Desa Juron sejak lama telah mewarisi kreweng atau tanah liat sebagai bahan tradisional untuk peralatan dapur. Selain itu, bentuk Monumen Kreweng merupakan sebuah simbolisasai dari tungku tradisonal yang menjadi warisan bernilai di Desa Juron.

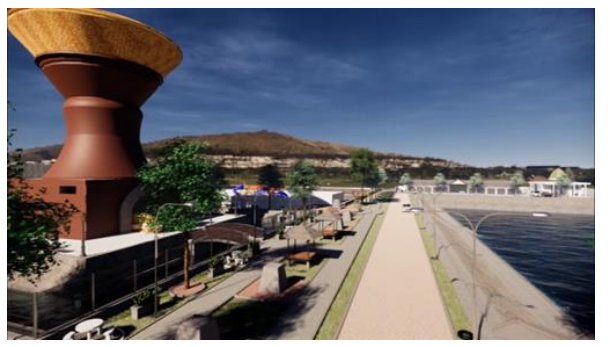

Gambar 1. Monumen Kreweng dengan view embung di depannya

(Sumber: Video “Monumen Kreweng”, 2019, Time code 00.02.03)

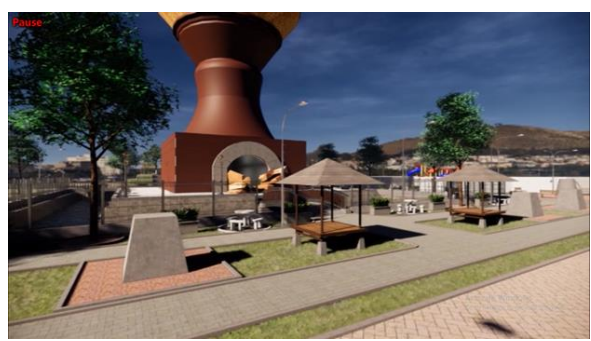

Gambar 2. Monumen Kreweng dengan taman rekreasi (Sumber: Video "Monumen Kreweng", 2019, Time code 00.02.18) 


\section{CAPTURE}

Monumen Kreweng dalam karya video animasi $3 D$ ini sebagai konsep diferensiasi dikarenakan "Monumen Kreweng" hadir sebagai ikon yang diambil dari kearifan lokal Desa Juron. Tentu, ini menjadi pembeda dengan kearifan lokal lainnya. Selain itu, Monumen Kreweng dengan ukuran yang besar ini mampu menjadi view yang menarik dan dapat meningkatkan kunjungan wisata di daerah Juron, dampaknya perekonomian daerah tentu beriringan akan semakin meningkat.

\subsection{Kolaborasi}

Karya video animasi 3D "Monumen "Kreweng" selain menyajikan identitas Desa Juron melalui Monumen Kreweng yang ikonik dan diferensiatif, juga secara ekspilisit memperihatkan bentuk kolaborasi dengan elemen yang lain. Video master plan ini tergambarkan Monumen Kreweng tidak berdiri secara simbolik, namun di sekitarnya dikelilingi beberapa lanskap di antaranya embung (perairan), taman, fasilitas umum, wahana water boom, dan food court. Artinya, video ini memperlihatkan bahwa secara ruang Monumen Kreweng berkolabarasi dengan elemen pendukung yang pada akhirnya akan membentuk sebuah pusat wisata.

Bentuk kolaborasi yang utama adalah menggandeng kekayaan alam yaitu embung, Embung atau cekungan penampung (retention basin) adalah cekungan yang digunakan untuk mengatur dan menampung suplai aliran air hujan serta untuk meningkatkan kualitas air di badan air yang terkait (sungai, danau). Desa Juron terkenal dengan embung, yang dalam hal ini mampu menambah landscape indah dari Monumen Kreweng. Monumen hadir sebagai sebuah kesatuan dan kolabarasi dari berbagi elemen pendukungnya termasuk embung yang menjadi pemandangan alamnya.

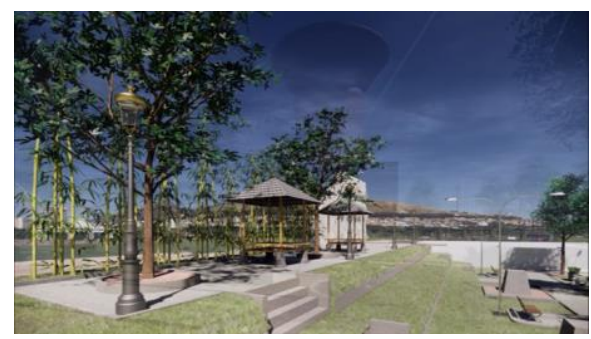

Gambar 3. Area taman Monumen Kreweng sebagai bentuk kolaborasi

(Sumber: "Monumen Kreweng", 2019, Time code 00.01.10)

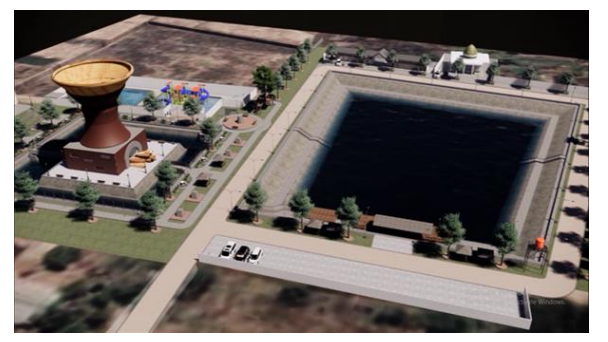

Gambar 4. Tampak atas area Monumen Kreweng terlihat kolaborasi dengan berbagai wahana

(Sumber: Video "Monumen Kreweng", 2019, Time code 00.01.15)

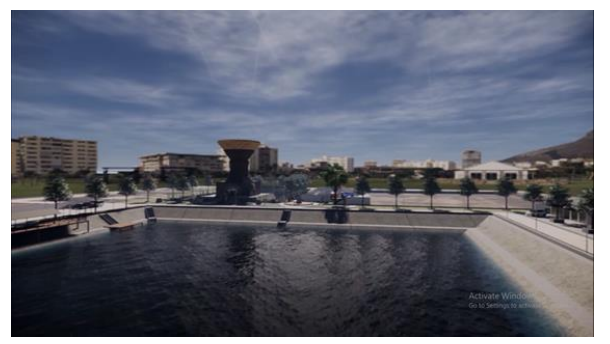

Gambar 5. Tampak depan Monumen Kreweng berkolaborasi dengan embung sebagai view (Sumber: Video "Monumen Kreweng", 2019, Time code 00.05.36) 
Sebuah visual brand penting untuk berkolaborasi dengan aspek yang lain guna meningkatkan varian serta memperkuat ikon yang dipilih sebagai strategi brandingnya. Karya video animasi 3D memperlihatkan upaya strategi brand daerah yang memiliki kesadaran kolabarasi pada aspek ruang. Monumen Kreweng bukan hanya memperlihatkan monumen berdiri secara megah, namun juga berkolaborasi dengan aspek ruang yang lain, seprti taman, wahana water boom, embung, dan juga fasilitas umum lainnya. Dengan melihat karya video animasi 3D "Monumen Kreweng" berbentuk kolaboratif itu akan terlihat jelas saling mempengaruhi satu sama-lainnya, sehingga mampu memberi gambaran tentang proyeksi branding Desa Wisata Juron di Sukoharjo.

\subsection{Inovasi}

Strategi brand agar memiliki kebertahanan di masyarakat yaitu produk yang dihasilkan harus inovatif. Dengan begitu, sebuah brand mampu bertahan lama di masyarakat, dalam bahasa komunikasi dikenal istilah Top of Main, yaitu pikiran masyarakat langsung terarah pada produk, jika produk memiliki inovasi. Dalam karya video animasi 3D animasi "Monumen Kreweng" mengambarkan beberapa inovasi yang ditawarkan dalam menciptakan brand pariwisata di Desa Juron, Sukoharjo. Inovasi yang paling utama adalah kreativitas mengolah bentuk
Monumen Kreweng. Monumen Kreweng ini mengambil ide dari bentuk tungku pembakaran, dandang, dan kukusan tradisional khas Desa Juron dengan berbahan tanah liat atau kreweng. Berikut bentuk transformasi inovatif dari Monumen Kreweng.
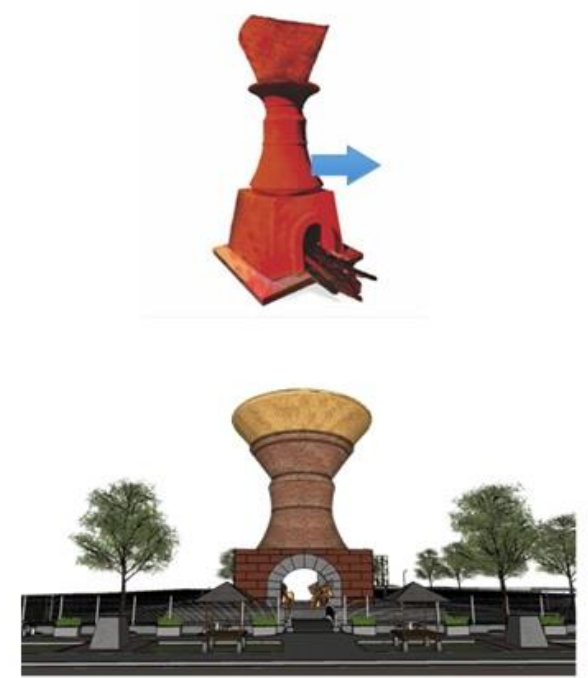

Gambar 6. Transformasi bentuk yang inovatif (Sumber: Video "Monumen Kreweng", 2019, Time code 00.05.36)

Beberapa aspek yang menjadi pertimbangan pada rancangan Monumen Kreweng di atas antara lain: (1) Dandang tradisional memiliki bentuk yang unik, proporsional, dan sangat responsif untuk digunakan sebagai bangunan yang memiliki ruang yang memadai untuk aktivitas manusia di dalamnya;

Pengelompokan ruang berdasar fungsinya dapat dibuat bertingkat yang akan memberikan kemudahan komunikasi dan koordinasi bagi penggunanya. Hal ini berkaitan dengan kemudahan akses dari satu ruang ke ruang lainnya. 


\section{CAPTURE}

Rancangan berbentuk dandang ini, direncanakan berukuran tinggi 20 meter, terdiri dari 3 lantai yang berfungsi sebagai museum kuliner dan perantauan. Museum ini nantinya digunakan untuk men-display beragam piranti dapur kuno, alat-alat yang digunakan untuk berdagang kuliner kuno seperti gerobak bakso, tenggok jamu gendong, dan lain-lain. Termasuk di dalamnya men-display beragam foto-foto kuno masyarakat perantau Desa Juron dalam aktivitas berdagang kuliner di seluruh Indonesia.

Monumen ini diwujudkan dengan material tanah liat eathernware setempat (area embung Desa Juron) dikomposisikan dengan tanah liat stoneware dari Pacitan, Jawa Timur. Pembentukan menggunakan teknik tekan menggunakan mesin cetak bata. Dinding dandang diciptakan dengan pembuatan batu bata besar berukuran $25 \times 60 \mathrm{~cm}$ disusun secara interlocking direkatkan dengan material semen. Pembentukan batu bata dilakukan dengan mesin cetak bata. Pembakaran dilakukan selama 12 jam dengan suhu 1200 derajat Celcius, yang dikerjakan di lokasi embung Desa Juron. Finishing menggunakan bahan pelapis clear batu alam yang menutup seluruh bagian keramik berbentuk dandang. Bahan pelapis tersebut akan menghasilkan warna transparan secara matt yang berfungsi melindungi dari pengaruh cuaca dan jamur. Inovasi dari segi bentuk dan material menjadikan
Monumen Kreweng mampu menjadi visual branding bagi pariwisata Desa Juron di Sukoharjo.

\subsection{Validasi}

Validasi dalam suatu brand digunakan untuk melihat tingkat penerimaan target audience, biasanya survey dilakukan untuk melihat tingkat penerimaan khalayak. Dalam konteks video animasi 3D ini, validasi yang dilakukan yaitu dengan studi publik dengan mengunggah video ini ke dalam platform digital (media sosial). Video animasi 3D dengan durasi 7 menit ini akan diunggah di kanal-kanal seperti Youtube, Instagram, dan kanal-kanal lainnya. Platform digital ini menjadi praktek validasi dari karya video animasi 3D dengan menggunakan pengukuran melalui view dan komentar pada aplikasi media sosial.

\subsection{Cultivate \\ Konsep cultivate menjadi ujung tombak dari ketahanan sebuah brand, mempertahankan brand visual menjadi tantangan tersendiri setelah menerpakan konsep diferensiasi, kolaborasi, inovasi, dan validasi. Praktik cultivate tak hanya cukup kolaborasi, namun juga bagaimana peran setiap pendukungnya memiliki kontribusi bagi ketahanan brand. Monumen Kreweng melalui video animasi 3D mengajak peran berbagai pihak untuk tetap mendukung sebuah brand yang cultivate.}


Pihak yang akan digandeng dalam mempertahankan brand visual Monumen Kreweng tentu masyarakat Desa Juron sebagai pihak mayornya, kemudian pihak instansi daerah melalui dinas pariwisata daerah, UMKM, dan tentu budayawan. Kolaborasi yang cultivate ini diharapkan mampu mendongkrak pariwisata Desa Juron Kabupaten Sukoharjo dengan brand visual "Monumen Kreweng". Pada titik ini, video animasi 3D "Monumen Kreweng" adalah sarana untuk menggandeng pihakpihak untuk terlibat dan berperan dalam mewujudkan kebertahanan Desa Wisata Juron yang berkesinambungan.

\section{SIMPULAN}

Strategi brand di era digital ini mengalami perubahan yang sangat signifikan. Strategi konvensional mulai perlahan ditinggal dan beralih ke media teknologi yang mudah diakses. Selain itu, media digital memiliki peran besar dalam mengubah komunikasi lebih informatif, cepat dan menjangkau segmen. Oleh karena itu, upaya yang dilakukan masyarakat Desa Juron, Kabupaten Sukoharjo dalam menciptakan brand pariwisata dengan media visual sangatlah tepat. Karya video animasi 3D "Monumen Kreweng" memuat strategi visual brand dalam meningkatkan industri wisata.

Karya video animasi 3D "Monumen Kreweng" setelah dilakukan analisis visual branding-nya diperoleh sebuah pemahaman bahwa dalam karya ini telah memuat strategi visual branding yaitu diferensiasi, kolaborasi, inovasi, validasi, dan cultivate. Diferensiasi terdapat pada karya Monumen Kreweng sebagai pusat perhatian dan kearifan lokal; inovasi yang ditampilkan yaitu bentuk Monumen Kreweng yang berukuran besar dan tinggi; dan eksplorasi bahan yang inovatif. Selain itu, bentuk berupa perpaduan tungku dan dandang yang merupakan peralatan dapur khas dari Desa Juron di Sukoharjo, kemudian validasi dilakukan dengan memanfaatkan platform media sosial untuk memberikan umpan balik dari konsumen tentang visual branding Monumen Kreweng. Konsep cultivate didorong oleh karya video animasi 3D "Monumen Kreweng" untuk menggandeng beberapa pihak untuk terlibat dan ikut serta dalam mewujudkan branding Desa Wisata Juron, sehingga mampu menjadi daerah tujuan wisata yang berdampak pada perkembangan daerah khususnya di Desa Juron, dan umumnya di Kabupaten Sukoharjo.

\section{DAFTAR ACUAN}

Neumeier, Marty. (2006). The Brand Gap. California: New Readers Publisher.

Noorwatha, I Kadek Dwi \& Wirawan, I Gusti Ngurah. (2020). "Strategi Desain Dari Visual Branding The $6^{\text {th }}$ International Seminar on Nusantara Heritage (ISoNH) 2017". Jurnal Segara Widya, 21-22.

Prayogo, Koko Is \& Sugihartono, Ranang Agung. (2016). "Directing Animation dalam Film Seri Seribu Satu Candi". CAPTURE: Jurnal Seni Media 


\section{CAPTURE}

Rekam, 8(1), 34-47. DOI: 10.33153/capture.v8i1.1899.

https://jurnal.isi-

ska.ac.id/index.php/capture/article/v iew/1899.

Ratna, Nyoman Kutha. (2010). Metode Penelitian: Kajian Budaya dan IImu Sosial Humaniora pada Umumnya. Yogyakarta: Pustaka Pelajar.

Santo. (2019). "Strategi Animasi Interaktif "Keliling Jawa". Jurnal Dimensi DKV Seni Rupa dan Desain, Vol.4, (2), 109-122.

Publisher:

Jurusan Seni Media Rekam

Fakultas Seni Rupa dan Desain

Institut Seni Indonesia (ISI) Surakarta

Available online at:

https://jurnal.isi-ska.ac.id/index.php/capture

How to Cite:

Marwanto, Aries Budi; Afrianto, Damar Tri \& Atmaja,

NRA Chandra Dwi. (2021). 3D Animation Video

'Monumen Kreweng' as A Visual Branding Strategy for

Tourism Village Juron. CAPTURE: Jurnal Seni Media

Rekam, 12(2), 196-206. 